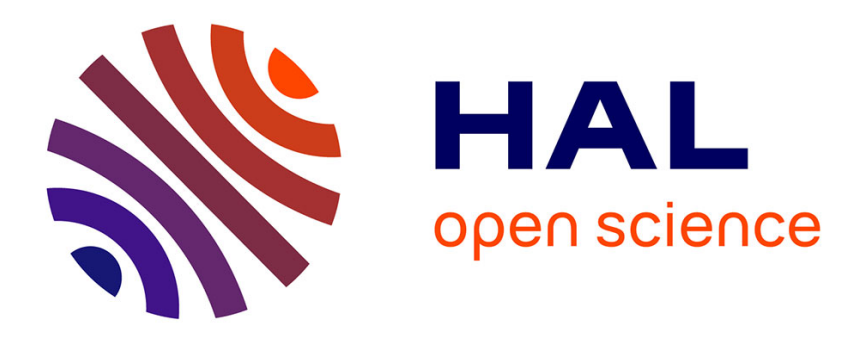

\title{
Disciplinary Collisions: Blum, Kalven, and the Economic Analysis of Accident Law at Chicago in the 1960s
}

\author{
Alain Marciano, Steve G. Medema
}

\section{To cite this version:}

Alain Marciano, Steve G. Medema. Disciplinary Collisions: Blum, Kalven, and the Economic Analysis of Accident Law at Chicago in the 1960s. Law and Economics as Interdisciplinary Practice, inPress. hal-01836082

\section{HAL Id: hal-01836082 \\ https://hal.umontpellier.fr/hal-01836082}

Submitted on 12 Jul 2018

HAL is a multi-disciplinary open access archive for the deposit and dissemination of scientific research documents, whether they are published or not. The documents may come from teaching and research institutions in France or abroad, or from public or private research centers.
L'archive ouverte pluridisciplinaire HAL, est destinée au dépôt et à la diffusion de documents scientifiques de niveau recherche, publiés ou non, émanant des établissements d'enseignement et de recherche français ou étrangers, des laboratoires publics ou privés. 


\title{
Disciplinary Collisions: Blum, Kalven, and the Economic Analysis of Accident Law at Chicago in the $1960 \mathrm{~s}^{1}$
}

\author{
Alain Marciano ${ }^{2}$ \\ MRE and Université de Montpellier \\ and \\ Steve Medema ${ }^{3}$ \\ University of Colorado Denver
}

\begin{abstract}
The University of Chicago occupies a central place in the history of law and economics. To this point, however, scant attention has been given in the literature to how the prospect of an economic analysis of law was received within the Law School at Chicago when the subject was in its infancy. In this paper we focus on the work of two prominent dissenters: Law professors Walter J. Blum and Harry Kalven, Jr. We show that, although immersed in economics and interacting with the main actors of the law and economics movement in the early 1950s, Blum and Kalven largely rejected economics as a possible and useful help for solving legal problems, both because of their concerns about the utility of economics in the legal realm and because of their sense that economics and law are grounded in fundamentally incompatible normative visions.
\end{abstract}

Keywords: Economic analysis of law, Chicago, Blum, Kalven, Liability, Tort Law, Automobile accidents

JEL codes: A12, B21, B41, K0

\footnotetext{
${ }^{1}$ Earlier versions of this paper were presented at the ANR workshop (Ecole Normale Supérieure de Cachan, France, 2010), at the History of Recent Economics conference (Duke University, 2011), at the University of Lausanne (seminar of the Walras-Pareto center, 2012), at the University of Paris 1 (CES seminar, 2013), at the Law and Society annual meetings (Boston, 2013), at the Center for International Research in the Humanities and Social Sciences (New York University, 2014). We thank all of the participants, for their comments. Usual disclaimers apply.

${ }^{2}$ Department of Economics, University of Montpellier, Rue Raymond Dugrand, CS 79606, F-34960 Montpellier, France; e-mail: alain.marciano@umontpellier.fr.

${ }^{3}$ Department of Economics, University of Colorado Denver, CB 181, PO Box 173364; Denver, CO 80217-3364, USA; email: steven.medema@ucdenver.edu.
} 


\section{Introduction}

The history of law and economics is tightly linked to the University of Chicago and its Law School. What is less well understood is how the law and economics tradition has evolved at Chicago since its inception in the 1930s. ${ }^{4}$ As Medema (1998, 2011; see also Harnay and Marciano 2009) has noted, there are really two law and economics traditions at Chicago. The first, which we shall label "law and economy," examines the impact of legal rules on the economic system. This is the law and economics of Henry Simons, Aaron Director and Ronald Coase, the economists who established and solidified the law and economics program at Chicago, and its goal is to inform economic analysis and economic policy making. The second, which we shall label the "economic analysis of law," applies the tools of economic analysis to the legal system. This is the law and economics of Gary Becker, Richard Posner and William Landes — and, indeed, makes up most of what is identified as "law and economics" today_ and its goal is to inform legal analysis and decision making (Fleury 2015).

The study of "law and economy" has a long tradition in economics, antedating Adam Smith, but is represented in twentieth-century America by the Institutionalist tradition of John R. Commons, Robert Lee Hale, Walton Hamilton, and others (many of whom were also associated with the legal realist movement), by Chicagoans such as Simons, Director and Coase, and by the New Institutional Economics. The "economic analysis of law," in contrast, is a distinctly modern creature. Its roots trace to the 1960s and early 1970s, when Yale's Guido Calabresi (1961; 1965a, b; 1970) was working out an economic analysis of accident law (Marciano, 2012; Marciano and Ramello, 2014), Becker (1968) developed an economic theory of crime and punishment, and

\footnotetext{
${ }^{4}$ Internalist discussions of this history can be found in Kitch (1983) and Coase (1993).
} 
Posner published his sweeping treatise, Economic Analysis of Law (1972). But the standard history suggesting that the economic analysis of law arrived on the scene in Chicago in the late 1960s and early 1970s and immediately took root there overlooks an important early episode in law and economics history at Chicago — one that involved a collision between the "law and economy" tradition and the emerging economic analysis of law, and in which the economic analysis of law —at Chicago, at least—came out the loser. The underlying story here is one of interdisciplinarity and its limits, of disciplinary definitions, boundaries and scope, and of differing perceptions as to the legitimacy of certain types of boundary crossing.

The "law and economy" tradition at Chicago dates to the appointment of Henry Simons to the Law School faculty in 1939 but its profile increased significantly with the appointment of Aaron Director following Simons' death in 1946. Under Director's influence, the late 1940s and early 1950s witnessed the development of the "Free Market Study" and "Antitrust Project," both funded by William Volker, ${ }^{5}$ which trained the lens of economic analysis on the legal institutions of the American capitalist system. But "law and economics" was anything but central to the Law School ethos at this time. Indifference and even outright hostility were much more the order of the day (Kitch 1983; Medema 2009, ch. 7), with a few exceptions. Among these exceptions were Walter J. Blum (1918-1994) and Harry Kalven, Jr(1914-1974).

Blum and Kalven, though largely absent from traditional histories of law and economics, were, as Dean Geoffrey Stone put it in 2007, two of the "towering figures who redefined and reconstituted the University of Chicago Law School after World War II"- standouts for their scholarship and their roles in institution building (Stone, 2007, p. 439). But they were also

\footnotetext{
${ }^{5}$ On William Volker and the Volker Fund, see the analyses by Van Horn and Mirowski (2009) and Van Horn (2009).
} 
important transitional figures in the history of law and economics, evidencing elements of both its "law and economy" and "economic analysis of law" threads. As such, their story provides insight into how legal scholars at Chicago attempted to grapple with the tension between traditional legal thinking and what economics might offer to the analysis of legal issues, as well as into the history of the interactions between actors from these different disciplines. Blum and Kalven were at once open to considering what economics might have to offer to the analysis of legal issues, interested in engaging with Chicago colleagues on this score, and ultimately critical of the normative conclusions for law drawn by others based on the use of economic logic. While they did not hesitate to invoke the economist's position, as they understood it, and to analyze economic arguments, Blum and Kalven consistently found themselves rejecting the economic approach that was soon to become so closely associated with Chicago on the grounds that it was unconvincing on logical, empirical, and ethical grounds.

The objective of this article is to explore the trajectory that led Blum and Kalven to a discussion and criticism of the use of economic arguments in the law. We begin with an examination of the early years that both of these scholars spent as members of the Law School faculty at the University of Chicago, demonstrating their lengthy immersion in economics and interactions with the colleagues in the economics department. We also discuss and analyze their arguments against expanding the use of economics in law and how they presented and refined them during a controversy that found them doing battle with Calabresi over the adaptation of the U.S. legal system to the problem of motor-vehicle accidents.

\section{Blum and Kalven, Engaged with Economics}

Walter Blum earned his undergraduate and law degrees (A.B., 1939; J.D., 1941) at Chicago, 
graduating first in his Law School class. His matriculation to the Law School in 1939 coincided with the appointment of economist Simons to the Law School faculty. Simons had been associated with the Chicago economics department for some years, teaching and writing (for professional and public audiences) on matters related to the U.S. monetary system, taxation, and the competitive/free-enterprise system. A 1930s controversy over the granting of tenure to Simons ended with his appointment in the Law School, where the Dean, Wilbur Katz, was attempting to build an interdisciplinary legal studies curriculum that included courses in economics and accounting. Simons' appointment, and his offering of a Law School course on "Economic Analysis of Public Policy," marked the inauguration of the economics tradition at the University of Chicago Law School.

Blum's exposure to Simons was early and extensive. He was a student in the economics course that Simons offered in the Law School and quickly became his "protégé" (Shaviro 2013, p. 3). ${ }^{6}$ Blum also took the Law School course in accounting taught by Katz, whose interdisciplinary perspective on law—one very much in keeping with the legal realist mood of the period - made him one of the forerunners of the "law and economics" field (Blum, in Kitch 1983, p. 168). The obvious proximity between Blum and the precursors of the law and economics movement, along with his "immersion" in economics, fed into the areas of research that Blum pursued upon joining the Law School faculty in 1946. His research agenda was tilted heavily toward topics - bankruptcy law, corporate law, and tax law-which, even at that time, were considered to have an "economic" aspect and, as it happens, tacked closely to Simons' own research interests. But it was not simply a matter of Blum publishing in areas with overt links to

\footnotetext{
${ }^{6}$ Blum recounted that he "got to know [Simons] as a result of drinking beer with him in Hanley's tavern about once a week over a period of about six or eight months" (in Kitch 1983, p. 179).
} 
economics. Blum's interest in economic issues also carried through to his teaching. When Henry Manne, one of the founders of the modern law and economics movement and a 1952 Law School graduate, reflected back on his student days, he recalled "It was clear to me very early that economics was important in most of the courses I was taking in law school," and Blum's tax course was one of the three examples he cited to illustrate his statement (Kitch 1983, p. 184). ${ }^{7}$ One of the two other examples cited by Manne, as it happens, was the course on torts that he took with Harry Kalven (Kitch 1983, p. 184).

Yet, Kalven's connection to economics was not as overt as Blum's. Kalven was, at least in the beginning, interested in more strictly legal issues. Like Blum, he had earned both his undergraduate and law degrees from the University of Chicago, and he joined the Law School faculty in 1945 — one year prior to Blum. Kalven's research focused on the functioning of the legal system and the role of juries, as well as the law of torts (including accidents), and he quickly became a leading authority on tort law, co-authoring, with Charles O. Gregory, one of the most widely used textbooks in the field, Cases and Materials in Torts (1959). Kalven's interest in economics built up progressively through formal and informal interactions with his professorial colleagues—both economists and lawyers—at Chicago. As Manne later related, no small amount of this came through informal interaction that took place over the daily afternoon tea in the Law School's student lounge, where Blum, Kalven, Bernard Meltzer, Ed Levi, Aaron Director and Allison Dunham could be found discussing legal questions from an economic perspective (Kitch 1983, 187).

\footnotetext{
${ }^{7}$ Blum used for his courses on taxation a "textbook" entitled Law and Economic Organization: Materials on Federal Taxation, published by the University of Chicago Law School (1947). He also co-authored with Katz a volume entitled Materials on Reorganization for the Course in Law and Economic Organization in the University of Chicago Law School, a revision of Katz's Materials on Bankruptcy and Reorganization for the Course in Law and Economic Organization in the University of Chicago Law School from 1942.
} 
This period also featured a "kind of roving seminar" each month in which Blum, Katz, Kalven, Malcolm Sharp, and Director regularly participated. Even Milton Friedman attended on a number of occasions. The seminars typically focused on an assigned reading which would then form the basis for the seminar discussion. Blum later noted that when Friedman presented his educational voucher plan to this group, "it had a great deal of influence" on him and on Kalven in particular. All of this affected Kalven's way of thinking about law. "As Harry began to develop his materials in torts," Blum said, "more and more he began looking for economic dimensions in the subject." Blum acknowledged that, viewed through the lens of modern law and economics these were "minor steps," but "compared to where we are today," he said, "they were important steps" (Kitch 1983, 186).

Blum and Kalven's intersection with "law and economics" had a number of facets, both direct and indirect. Their interest in the light that economics could shed on social and political issues was sufficiently strong that they agreed to participate in the organization of a three-day conference, held in early April 1951, on "The Economics of Mobilization," spearheaded by Aaron Director and sponsored by the University of Chicago Law School with financial support from the Volker Fund. The objective of this conference, the proceedings of which were published as Defense, Controls, and Inflation (Director 1952), was, as Director spelled out in his foreword to this volume, to discuss "issues concern[ing] the effectiveness of alternative measures to achieve economic mobilization [for war] as well as the influence of these measures on the more permanent objectives of public policy" $(1952, \mathrm{p} . \mathrm{v})$. The 'markets vs. controls' theme that overarched the discussion of how best to manage wartime resource allocation was one that was “of obvious importance to law and economics" (Director 1952, p. v) and reflected the broad 
nature of the "law and economy" approach that characterized the first several decades of law and economics at Chicago.

Blum and Kalven's most extensive early engagement with the interaction of economics and law came in their analysis of the case for progressive taxation $(1952,1953)$. This work carried forward Simons' interest in the subject, as seen particularly in his 1938 book, Personal Income Taxation. In contrast with the approach that later was to dominate the economic analysis of law, and its Chicago variant in particular, Simons had argued that the discussion of the appropriateness of a progressive tax system should be grounded beyond economics proper. "The case for drastic progression in taxation," he said, "must be rested on the case against inequalityon the ethical or aesthetic judgment that the prevailing distribution of wealth and income reveals a degree (and/or kind) of inequality which is distinctly evil or unlovely" (1938, 18-19). Moving the discussion in this direction, beyond a more narrow economics of the issue, for Simons, would reveal that "the case for equality (for less inequality) is enormously stronger than any utility foundation on which it can be rested" $(1938,14)$. Blum and Kalven quoted Simons approvingly on this score (e.g., 1953, 72) and praised him for "insisting that in any discussion of progression the problem of inequality 'be dragged out into the open"' (1952, 487; see also 1953, 73).

But Blum and Kalven did not rest their position on moral arguments alone. Taxation, for them, also had important legal and economic dimensions. They brought numerous references from the economics literature into their discussion, though, as David McCord Wright pointed out in a review of their book, Blum and Kalven ignored the important recent writings on progressive taxation by economists including Paul Samuelson, Tibor Scitovsky and D.H. Robertson (McCord Wright 1954, p. 583). One particularly noteworthy feature of this discussion, in light of their later 
debate with Calabresi on accident law, is their treatment of the relatively technical issue incentives and deterrence - the potential effect of progressive taxation on economic incentives. Here, we find Blum and Kalven taking issue with the incentive effects central to economists' analysis of taxation. Progressive taxation, they asserted, "does not impair the incentive" to find the most attractive jobs — which "are also the best paid"- because individuals who try to get better jobs tend to do so at least as much for the "prestige" that accompanies the high salary as for its income-augmenting aspect $(1953,438)$. In fact, they argued, "there is some plausibility to the notion that being subject to higher tax rates may even be an inducement to persons to work harder in order to maintain their net position after taxes" (p. 439). In fact, they considered the "technical"- that is, the economic — arguments to be among "the weakest" of those offered in support of a progressive tax structure, finding it "hard to gain much comfort from the special arguments, however intricate their formulations, constructed on notions of benefit, sacrifice, ability to pay or economic stability" $(1952,519)$. Economic arguments, then, could not be accepted in straightforward fashion, but instead needed to be evaluated alongside with those from other intellectual arenas.

Although Blum and Kalven developed their analysis of progressive taxation when law and economics had already a foothold at Chicago, this work bore no apparent marks of connection to the people then involved in what are now generally considered the early manifestations of the law-and-economics movement at Chicago. Though the links to the work of Simons are obvious, both the subject matter and perspective brought to bear were distinct from the Director-led "Antitrust Project" around which Chicago law and economics had come to revolve during the 1950s. ${ }^{8}$ As we shall see, however, their hesitance about the conclusions that

\footnotetext{
${ }^{8}$ The areas covered by the Antitrust Project were vertical integration, predatory pricing, tying arrangements, the
} 
one could draw based on the insights of economic theory did not deter Blum and Kalven from taking up economic analysis when they were of the mind that it might be useful for their work.

\section{Car accidents, Tort Law, and Compensation Plans}

Blum and Kalven took largely independent research paths in the years following the publication of their book on progressive taxation, with Blum continuing along the tax path and Kalven focusing on civil liberties and torts - in particular, accidents, insurance, and compensation. This last was anything but a purely academic exercise, for the 1950s saw a growing concern in the US with automobile accidents and highway safety.

In the late 1950s, the number of car accidents and associated fatalities in the US rose dramatically. Annual of fatalities increased by 52 percent - from 36,981 to 56,278 - between 1958 and 1972 (National Council for Highway Safety), ${ }^{9}$ leading one commentator to remark that "automobility was no longer an historically progressive force for change in American civilization" (Flink, 1972,452). The toll associated with automobile accidents was both striking and troublesome for obvious human reasons, but also for what it cost American society. Franklin, Chanin and Mark put forward some particularly impressive figures in documenting the economic toll of accidents generally, finding that "lost wages and medical expenses alone amount to almost $\$ 5,000,000,000$ annually $\ldots$ and the total economic cost of accidents may well exceed

Sherman act, fair trade and trade regulation. Coase (1993, p. 242) later emphasized the disconnect between Simons' work - of which Blum and Kalven's was an offshoot - and the later Chicago approach to law and economics. Blum and Kalven's approach also likely would not have appealed to the Antitrust Project's funder, the Volker Fund. See Rothbard (2010).

${ }^{9}$ See http://www.cdc.gov/nchs/data/dvs/lead1900_98.pdf. The death rate from automobile accidents had increased by 500 percent between 1912 and 1932, with more than 30,000 deaths occurring in 1930, while the death rate from other types of accidents fell by 20 percent during that same period. See Anderson, Heaton and Carroll (2010, p. 23), Abraham (2008, pp. 70-71), and Smith, Lilly, and Dowling (1932, p. 786). 
$\$ 15,000,000,000 "(1961,1-2)$. Automobile accident costs loomed large within these totals. ${ }^{10}$ The legal costs associated with these accidents only added to that total, as the number of lawsuits related to car accidents increased steadily_by 50 percent between 1955 and 1970 (Anderson, Heaton and Carroll, 2010, 28). In Cook County, which was home to the University of Chicago, lawsuits arising from automobile accidents represented 66\% of the civil cases between 1960 and 1975 (Peterson and Priest, 1982, 6). Not surprisingly, the dramatic increase in accident numbers brought with it an increase in automobile insurance liability premiums, from $\$ 2.4$ billion in 1955 to $\$ 8.9$ billion in 1970 (Anderson, Heaton et Carroll, 2010, 28), ${ }^{11}$ even though insurance was not compulsory in any of the states in the Union. The lack of compulsory automobile accident insurance meant that compensation was often granted only if fault or negligence was proved at trial, a fact that played a significant role in the increased number of lawsuits. As such, what people could obtain in the way of compensation for accident losses depended, at least partly, on the legal system.

The heavy reliance on the courts for dealing with accident-related claims led to a number of problems, including significant delays in the resolution of injury claims and mismatches between injuries and compensation awards. A study conducted by James and Law in 1951 showed that very little progress had been made since 1932, when the first compensation plan for automobile accidents was proposed, for "the same facts and the same problems are still with us

\footnotetext{
${ }^{10}$ Automobile accidents represented roughly a third of all accident-related fatalities at this time.

${ }^{11}$ It is not only the number of car-accidents related lawsuits or the costs of liability that were problematic but also the strategic behaviors that this implied. As Anderson, Heaton and Carroll stress, medical—overall and per-capitaexpenses increased over the same period of time. This led "injury victims" to search for more "amounts from defendants to cover that care." (2010, p. 29). And attorneys started to devise methods that would allow victims to obtain "much higher verdicts for pain and suffering than had been common" (Abraham, 2008, pp. 83-84; cited in Anderson, Heaton and Carrol, 2010, p. 28).
} 
today" $(1952,81) .{ }^{12}$ Writing seven years later, James found that the central problems remained unresolved. There was "good reason to believe that the bulk of automobile victims fare no better today than they did at the time of the Columbia Study," he argued, and the same "underlying inequities" continued to plague the payments system $(1959,424)$.

Many scholars actually suggested that these compensation issues could only be effectively resolved through a turn away from the legal system toward a centralized, administrative solution. Under such a system, victims would not be fully compensatedparticularly for non-economic losses, such as pain and suffering — and liability would no longer be based on fault or negligence. ${ }^{13}$ Kalven $(1955,1959)$ reacted strongly against such proposals. Though he found much to agree with in the basic diagnosis of problems with the tort-based system of accident law, the idea of removing fault from the equation, he felt, would throw out the baby with the bath water. While some considered fault and outdated notion, Kalven insisted that it is a "deeply held category of thought in our culture" $(1959,686)$. More importantly, however, it was one of "the possible big ideas for allocating liability" - one that, for Kalven, made “enough sense to always deserve serious attention" (1959, 686; emphasis added). Though a significant segment of the literature was moving toward the position that loss spreading or the compensation of victims should be the chief function of tort law, Kalven was adamant that liability allocation should remain tort's primary objective. As we shall see, these conflicting visions of tort law's ultimate purpose were at the heart of Blum and Kalven's debate with

\footnotetext{
${ }^{12}$ The proposal was made in the report of the "Committee to Study Compensation for Automobile Accidents," also known as the "Columbia Report" or "Columbia Study." Car accidents and the compensation of victims were viewed as a problem already in the 1930s. The Columbia report suggested that compensation should be paid from a general fund and that accident losses should be spread over a large population with a view to providing appropriate compensation to the maximum number of victims.

${ }^{13}$ See, e.g., Ehrenzweig $(1951 ; 1955)$ and Green (1958).
} 
Calabresi.

\section{Applying Economic Analysis to the Law of Accidents}

\section{A. Calabresi and the case for economics}

Though their most influential work on accident law was still ahead of them, Blum and Kalven were anything but ignorant of the debate around torts, liability and accidents when Guido Calabresi arrived at the University of Chicago Law School in 1960 to present a paper on the subject. He had been invited by the Dean, Edward Levi, as part of an effort to to lure Calabresi to Chicago. At that time, Calabresi had only recently assumed a professorship at Yale ${ }^{14}$ and had just one paper written: "Some Thoughts on Risk Distribution and the Law of Torts" (1961). ${ }^{15}$ This paper was to form the basis for Calabresi's seminar.

Calabresi's analysis in the paper posed a stark challenge to the received legal approach to accident law. For Calabresi, the only question lawyers should concern themselves with was "when and how ... to distribute" the risk, or losses, associated with accidents $(1961,500)$. His argument, in essence, was that tort law is an optimal-allocation problem-a problem in economics rather than one to be addressed by reference to traditional legal norms and concepts. This, as Calabresi noted, put him squarely at odds with the position taken by Gregory and Kalven

\footnotetext{
${ }^{14}$ Calabresi graduated from the Yale Law School in 1958 and then spent a year clerking for U.S. Supreme Court Justice Hugo Black.

${ }^{15}$ This paper had been several years in the making. In 1955, while still a law school student, Calabresi wrote an essay entitled "Some Thoughts on the Distribution of Risks and Insurance" as part of his application for a position on the staff of the Yale Law Journal. The paper received the prize for the best student essay, which included the promise of publication in the Journal, but its appearance was delayed until 1961 because of, as Calabresi noted some thirty years later, the "cold reaction [of the] outgoing board" (Calabresi, 1991a, p. 1482). This paper was eventually published as "Some Thoughts on Risk Distribution and the Law of Torts," and it appeared in print at almost the same time as another of the pioneering works in the modern field of law and economics, Ronald Coase's article, "The Problem of Social Cost" (1960). Coase's article, though bearing a 1960 publication date, actually appeared in the late winter or early spring of 1961. These articles represented two of the earliest attempts to apply modern price-theoretic economic reasoning to analyze common law problems and, specifically, to apply market principles to questions of legal liability for harm.
} 
(1959) in their casebook on torts. For Gregory and Kalven, the central question of tort law was whether liability for accident-related harms should be grounded in the legal conception of individual fault or instead should be distributed more broadly, on a no-fault basis. Calabresi argued that this ignored what he considered the central problem in tort law-how to compensate victims of accidents, spread losses and distribute risks. ${ }^{16}$ For Blum, and even more so for Kalven, who had defended fault-based liability not only in the casebook on torts but in his above-noted criticisms of auto-compensation plans, ignoring fault as a criterion for liability and focusing on compensation made little sense.

Calabresi's interest in applying economics to the analysis of accident law had its roots in his extensive economics training at Yale and Oxford. As he moved through his legal studies at Yale, following his return from Oxford, Calabresi began to sense that economics could provide insight into certain problems of tort law, and the paper that eventually became his celebrated 1961 article on accident law represented his initial attempt to bring economic thinking to bear on a torts-related issue. Though space limitations preclude a full exposition of Calabresi's use of economic reasoning here, two findings must be noted.

First, and like Ronald Coase, who was working along similar lines during this same period, ${ }^{17}$ Calabresi found that there are some situations - those in which the pricing system is able to account for all relevant costs — where economics cannot provide guidance for the assignment of accident liability, because the allocation of resources will be identical regardless which party is made liable $(1961,506) .{ }^{18}$ But in many more cases, he said, the pricing system

\footnotetext{
${ }^{16}$ In this, Calabresi had been influenced by his Yale Law professor Fleming James (Marciano and Romaniuc, 2015).

${ }^{17}$ Coase was on the University of Virginia faculty at this time and moved to the University Chicago Law School in 1964.

${ }^{18}$ As in the case, for example, of workers compensation, where holding employers or workers liable for accidents would have identical effects, channeled through the labor market into wages, etc., a result that had been well
} 
does not lead to the internalization of all accident-related costs, as a result of which it actually does matter which party is made to bear the loss. The determination of liability in these situations, Calabresi argued, should be based on economic criteria rather than ethical ones, with efficiency considerations — specifically, the minimization of accident-related costs - governing the determination of liability for damage.

Calabresi's rationale for bringing efficiency into the mix posed a stark challenge to traditional legal thinking. Criteria such as justice and fairness, he said, are too "vague," too general and not practical enough to serve as guideposts for judicial decision making $(1961,501)$. The appropriate justification for liability assignment was what he termed "the 'allocation of resources' justification" $(1961,502)$, the theory underlying which suggested to him that "the most desirable system of loss distribution ... is one in which the prices of goods accurately reflect their full cost to society" $(1961,505)$. Accomplishing this required not simply that the cost of accidents be placed on someone, but on the agents who could avoid them most cheaply. That was Calebresi's second finding.

\section{B. The answer from Blum and Kalven}

The circulation of Calabresi's paper at Chicago prior to his seminar had provided both Blum and Kalven with the opportunity to read it in advance. They found the paper brilliant, Kalven greeting Calabresi by exclaiming, "I wish I had written an article like that when I was your age!" Nonetheless, they disagreed completely with its contents. Kalven even insisted that the paper was “all wrong” (Calabresi 1975, 69).

Though Calabresi's article was published in 1961, not long after his visit to Chicago, it

established in the economics literature for several decades See Marciano (2012) and Medema (2014b) for discussions of the commonalities and differences between the arguments of Calabresi and Coase. 
was not until 1964 that Blum and Kalven offered a published response to his economics-infused argument — stimulated in part, as it happened, by Calabresi's invitation to have them deliver the 1964 Schuman Lectures at Yale Law School. These lectures, subsequently published in the University of Chicago Law Review as "Public Law Perspectives on a Private Law Problem: Auto Compensation Plans" (1964), attempted both to clarify the nature of their disagreement with Calabresi and, more broadly, to express their opposition to proposed automobile accident compensation plans that would move the system away from its basis in fault. It is only the former aspect of their analysis, though, that concerns us here. But Blum and Kalven also objected to the methodology employed by Calabresi in his analysis of accident law, that of economic analysis and, specifically, minimization of the costs of accidents.

Blum and Kalven's assessment of the accident law literature suggested to them that economics appeared to be increasingly in play as a tool that might shed light on the determination of liability. Indeed, they said, the suggestion that lawyers look to economic analysis had recently become "the fashionable response" (1964, 692, emphasis added). ${ }^{19}$ They found this economic turn objectionable, though, and for two reasons.

First, Blum and Kalven did not believe that economic analysis was capable of informing the theory of legal liability for accidents, in that it could not pinpoint a legal rule to govern liability assignment (1964, 692-703). Both Calabresi and Coase, they noted, had demonstrated that, under certain conditions, the determination of liability will not affect the allocation of

\footnotetext{
${ }^{19}$ See the references given by Blum and Kalven (1964, p. 692). Among them, of course, one finds Calabresi. Later, they also noted that "economic analysis seems to be in command of a firm blueprint for inquiry." Walter J. Blum Papers, Box 31, Folder 2, Document 20, "Economic Analysis," n.d., p. 1. All references to "Document "' in the subsequent discussion refer to this box and folder. Of course, it is possible that Blum and Kalven's proximity to economics-inflused discussions of legal issues at Chicago also informed (and perhaps biased somewhat) this opinion.
} 
resources. Calabresi had argued that there was no allocative distinction between alternative liability rules when markets work smoothly, and Coase had shown that if transacting is costless, agents will bargain to the outcome that maximizes the value of output regardless of where liability is initially placed. ${ }^{20}$ Because allocations do not vary with legal rules under such conditions, Blum and Kalven pointed out, economics is of no assistance in determining the appropriate rule for assigning liability. And when these restrictions are loosened-when markets do not function smoothly and the exchange process is costly—-the liability assignment does affect resource allocation, but economic analysis does not have the capacity to predict, and so to tell us, which rule among the alternatives can be relied upon to best promote efficiency $(1964,701)$. The implications, for Blum and Kalven, were not friendly to the economist: "To exaggerate only a little," they said, "when the economist is helpful he says that the legal problem is not worth arguing about; when he finds the legal problem consequential, he cannot be helpful in fashioning a solution" $(1964,703)$.

More concerning to Blum and Kalven was the fact that economics and law do not have the same objectives at their respective hearts. At issue was what they considered the "sharp collision" between the lawyer's criterion of "justice" and the economist's concern with resource allocation and efficiency. ${ }^{21}$ Foreshadowing the debates over the economic analysis of law that were to take place during the 1970s and 1980s, Blum and Kalven argued that questions of justice and equity, which are "the ultimate concern of the law" and which "the law cannot escape its obligation to answer, appeared to lie beyond the scope of economic analysis $(1964,703,702$,

\footnotetext{
${ }^{20}$ Though Blum and Kalven found Coase's negotiation analysis interesting and were the first to reference it within the legal literature, they considered it rather unhelpful because they found the idea of prior negotiation among the parties to an accident a bit far-fetched.

${ }^{21}$ Document 2, p. 10.
} 
emphases added). Given that the question of justice "is one on which our hypothetical economic advisor takes no position" $(1964,703)$, they were left to conclude that the economist was not the one to whom the law should turn to resolve the question of how best to deal with accident-related harms. This was exemplified in Calabresi's use of economic thinking to remove fault from the equation, thereby moving the goals of law in non-traditional directions. ${ }^{22}$ "The law," they said, "ought not to break sharply with the moral traditions of the society, as it would if it no longer recognized fault and personal responsibility in human conduct." ${ }^{23}$ Economic analysis—and, one could argue, interdisciplinarity in general—-thus posed a threat not just to traditional legal methods but to legal and social norms.

\section{Struggling with Economics, 1966-1967}

\section{A. Car accidents and the law: the ongoing debate}

Blum and Kalven's 1964 article did anything but mark the end of the discussion. In 1965, they attempted to take their case to a broader audience by publishing a book that bore the same title as their 1964 article and utilized the same arguments. Calabresi, meanwhile, undertook to elaborate and defend his own position. In 1965, he published "The Decision for Accidents: An Approach to Nonfault Allocation of Costs" (1965a), an extension of the central themes of his 1961 article, and "Fault, Accidents and the Wonderful World of Blum and Kalven" (1965b), which responded directly to Blum and Kalven's critique of his position and of the economic approach generally. Each of these pieces, the first published in the Harvard Law Review and the second in the Yale Law Journal, further developed Calabresi's arguments for allocation of liability based upon on

\footnotetext{
${ }^{22}$ On the outward turn of law during this period, see, e.g., Posner (1987).

${ }^{23}$ Document 1, p. 14.
} 
the economic principle of cost minimization, but his basic line of reasoning did not change. ${ }^{24}$

Calabresi insisted that questions about liability and the goal of accident law "are not meant to herald a metaphysical search for ultimate causes" (1965a, 725). Such "[g]reat moral issues," he argued, are a matter of "collective choice" and have to be "decided in whatever political way our society chooses to decide moral questions" (1965a, 717). When it comes to everyday life situations, by contrast_-dealing with "rotary mowers versus reel mowers" or "one method of making steel as against another"-we are dealing with "questions difficult of collective decision" (1965a, 717). These situations, he argued, must be resolved on a case-bycase basis and grounded in practical considerations rather than ethical principles. Economics is ideal for resolving these more practical issues, he said, since "the marketplace serves as the rough testing ground" (1965a, 717).

The significance of automobile accidents costs, meanwhile, was increasingly on the public radar. Alfred Conard's 1964 article on "The Economic Treatment of Automobile Injuries" and his related book, Automobile Accidents Costs and Payments: Studies in the Economics of Insuring Reparations (Conard et al. 1964), published that same year, provided empirical evidence for the broad scope of accident-related costs borne by victims and by society as a whole. The increasing toll of automobile accidents motivated the passage of the National Traffic and Motor Vehicle Safety Act and the Highway Safety Act in 1966-by which time, as President Lyndon Johnson noted when signing the bill into law, automobile fatalities had reached a number nearly triple that of the lives lost in all of America's wars. ${ }^{25}$

Between the currency of the accident problem and Calabresi's critique of their arguments,

\footnotetext{
${ }^{24}$ See, for example, the discussion in Medema (2014b).

${ }^{25} \mathrm{http}$ ://www.presidency.ucsb.edu/ws/index.php?pid=27847
} 
Blum and Kalven had ample justification to press forward with their case for the redesign of accident law. This time, though, their salvo was aimed directly at Calabresi. "The Empty Cabinet of Dr. Calabresi: Auto Accidents and General Deterrence" was published in the University of Chicago Law Review in 1967, and the archival record reveals the processes through which they developed their argument. Beginning in January 1966, Blum and Kalven exchanged a lengthy stream of memoranda, notes, and drafts of ideas which demonstrate the extent of their concern not just with the details of Calabresi's proposal, but with the appropriateness of using economic analysis to inform legal reasoning — an approach that they seem to have considered a true threat to traditional legal methods.

Befitting a discussion that was taking place on boundaries between disciplines, the archival record demonstrates that Blum and Kalven went to some lengths to improve their understanding of economic analysis as they prepared a response to Calabresi's attack. Evidence for this can be found throughout the notes and memoranda they exchanged in the process of drafting their response, in their notes from a conversation with Chicago economist Harold Demsetz, several mimeographed pages from the famous Henry Simons Syllabus for Economics 201 ("The Divisional Course in Economics" for University of Chicago undergraduates), and repeated references to Chicago economist George Stigler's approach to dealing with problems of deterrence. ${ }^{26}$ Why would Blum and Kalven go to this effort rather than simply rejecting

\footnotetext{
${ }^{26}$ It is unclear by what means Blum and Kalven arrived at a sense for Stigler's views on the subject of deterrence; there no record of correspondence between them and Stigler in the Blum papers or the Stigler papers, and there is nothing in the articles that Stigler had written to that point which is suggestive. Apart from personal conversations, of which there are no record, one possible source of this view is Stigler's discussion of divergences between private and social costs in the 1952 and 1966 editions of his book, The Theory of Price - the 1966 edition of which took up Coase's argument explicitly. Stigler mentions the possibility of using a tax to achieve deterrence (e.g., 1952, p. 105), and this is the context in which Blum and Kalven reference Stigler in their discussion. Stigler was also quick to draw the conclusion, from Coase's analysis, that law is often without effect on the allocation of resources. There is no mention of Stigler in either of Blum and Kalven's articles on accident law - a fact that is less surprising when one understands that Stigler was an ardent proponent of the application of economic reasoning in the legal realm.
} 
economics out of hand as a lens through which to analyze legal problems? It is reasonable to surmise that their attitude was at least in part a result of the economic tradition in which they had been steeped at Chicago, going back to their student days. Having seen how economics could inform the discussion of some legal issues, they clearly did not want to reject the possibility that economics could inform the discussion of accident law without first having examined the details of the proposal that economists and economic reasoning would favor to minimize the costs of accidents— general deterrence. ${ }^{27}$ But their attitude seems to have gone beyond one of mere respect: Their hope seems to have been to discover an argument, grounded in economic analysis, that might point the way to their own favored system, one involving social security.

\section{B. General Arguments Against Economics}

As with their 1964 article, the notes they took and memoranda they wrote when preparing "Empty Cabinet" found Blum and Kalven emphasizing the divergent normative visions of economics and law — that while the economist is concerned with efficiency, "the primary concern of the law has been the corrective justice aspect of the matter." ${ }^{28}$ The question of which party should bear the burden of losses was, in their reading of the common law tradition, "a question of fairness. ${ }^{29}$ This distinction, and their desire to "bring justice back into the discussion" (1967, 264), were at the heart of Blum and Kalven's 1967 assault on Calabresi's reasoning. From where they stood, the use of economics and economic criteria is not sufficient for law. The domain of law, for Blum and Kalven, is one on which the economist, at least so far as prescription goes, cannot trespass, for within law "there very likely are hidden values that cannot be translated into

\footnotetext{
${ }^{27}$ Blum and Kalven noted in their exchanges that "General deterrence is a familiar objective to the economist," and that when one looks at the arguments in support of general deterrence, "[m]ost of the talk comes from the world of economics." (Document 1, pp. 18, 16).

${ }^{28}$ Document 10, p. 2.

${ }^{29}$ Document 1, p. 2.
} 
economic costs, such as the value of having individuals understand why they are being subjected to a special tax and the value of not departing too lightly from traditional and accepted ways of doing things" $(1967,266)$. The values of law, then, made a truly interdisciplinary collaboration between economists and lawyers difficult to envisage.

But Blum and Kalven found other, more practical reasons to be skeptical of benefits of an economic analysis of law. First, they questioned the empirical foundation underlying the claims an economist would make regarding human behavior within the legal realm-a concern that seems to be rooted in their sense that the economist here is operating outside of his area of primary expertise. "What," they asked, "do we know that shows that general deterrence ever works? What is the economists' expertise and experience here? With what kind of accident? Or is the point simply that as price goes up, demand goes down; and that people with variable costs will try to reduce these costs?"30 This, of course, led them to question the deterrence thesis that was at the heart of Calabresi's economic analysis of accident law, but their concerns were much larger than this, going to the issue of whether the economist's contention that the basic behavioral assumptions and the conclusions drawn from them translate outside of the traditional economic realm had any substance. At a minimum, Blum and Kalven questioned the economist's willingness to make such a leap without having done the sort of empirical work necessary to ground these conclusions. ${ }^{31}$

These concerns led directly to Blum and Kalven's second argument against economics: Absent such empirical evidence, they were not willing to walk down the behavioral road with the economist, at least when it came to matters related to automobile accidents. In particular, Blum

\footnotetext{
${ }^{30}$ Document 5, p. 3.

${ }^{31}$ See also Document 11, p. 2; Document 16, p. 1; and Document 18, February 4, 1966, p. 1.
} 
and Kalven questioned the assumed propensity of motorists to adapt their driving habits in response to a legal framework, such as that advocated by Calabresi, which imposes the entire cost of accidents on motorists. The disconnect between their view of human behavior within the legal realm and the economist's perspective is reflected in the seeming disbelief with which they reacted to a conversation on this subject with Demsetz. "[E]verything the economist says here," they noted, "rests on the notion that humans can be made to change their conduct and that different configurations of conduct result in different degrees of efficiency in the utilization of resources." ${ }^{32}$ And, at a minimum, Blum and Kalven were suspicious of the idea that legal rules inevitably functioned as price incentives and thus, in the case of driving, that increases in these "prices" would induce individuals to exercise additional precaution. Echoing their earlier assessment of the questionable links between income tax rates and labor-market incentives, noted above, Blum and Kalven argued that "since the personal safety of the individual driver will almost certainly be involved in any accident, what reason is there to believe that the sanction of price will operate in instances where the sanction of personal safety has failed to operate?" 33 Beyond this, they insisted that the incentive to avoid a charge of negligence under the extant fault-based system already induced motorists to exercise maximum precaution, meaning that the move to a no-fault system such as that advocated by Calabresi would not result in additional deterrence (e.g., 1967, 252, 254). ${ }^{34}$ In short, Blum and Kalven believed that existing incentives induce maximum precaution on the part of motorists and that additional price incentives will

\footnotetext{
${ }^{32}$ Document 4, p. 2.

${ }^{33}$ Document 5, memo from Blum to Kalven, "Questions and Reactions on Re-reading Calabresi," October 6, 1966, p. 2.

${ }^{34}$ The economist would object to this argument, pointing out that since the probability of being found negligent under a fault-based system is less than 1, meaning that additional precaution will reduce expected costs.
} 
have no further deterrent effect. ${ }^{35}$

But even if the law actually does provide the price incentives suggested by economists, Blum and Kalven were not convinced that agents could or would make the "meaningful calculation" necessary to assess the benefit-cost tradeoff between additional precaution and, say, a $\$ 100$ savings on insurance premiums. The typical driver, they contended, "is likely to find the economic calculus somewhat remote and difficult." ${ }^{36}$

Blum and Kalven's final concern with the economic approach brought them back around to their emphasis on traditional notions of justice: The economist's neglect of distributional considerations in favor of those related to efficiency. In the case of automobile accidents, they stressed that a deterrence system, by making a motorist liable for injuries to others that are not attributable to that motorist's negligence, involves an "injustice." ${ }^{37}$ Even if the economic argument is correct up and down the line and strict liability does, in fact, have the efficiency properties asserted by Calabresi, this system provides no rationale grounded in justice for making motorists bear all of the costs, including for accidents in which they were not negligent. Though the economist acknowledges that injuries from accidents affect the distribution of income and wealth, these effects "would not bear upon his proposal for optimizing accident conditions." Instead, he would respond by "disclaim[ing] any interest or competence, as economist, in such questions of distribution" or by asserting that "auto accident injuries are no different from other misfortunes; and that if welfare payments are thought desirable, they should be based on income and wealth status and not on the nature or cause of the particular misfortune." ${ }^{38}$

\footnotetext{
${ }^{35}$ For more details on Blum, Kalven and Calabresi and rationality, see Marciano and Romaniuc (2015).

${ }^{36}$ Document 18, memorandum from Kalven to Blum, "Further Thoughts on Super-Carefulness," February 4, 1966, p. 4.

${ }^{37}$ Document 10, p. 3.

${ }^{38}$ Document 10, p. 1.
} 
Though Blum and Kalven were not finding the economist of much use on the justice front, they did find one opening that seemed, to them, to provide some scope for harmony between the economist's views and their own. If the economist was concerned about policies to deal with the distributional effects of auto accidents, they suggested, he would insist that the measures employed not impact incentives in such a way as to affect the attainment of the optimal level of accidents. This led them to conclude that such an economist would be likely to favor a system of government transfer payments to victims not unlike what they had proposed in their 1964 article. Levying a general tax on motorists to create a fund out of which victims would be compensated would not, in their estimation, impact incentives, leaving them convinced that no less an economist than Stigler would find this system "desirable." ${ }^{39}$ In essence, the economist could potentially be useful to the law by suggesting efficient mechanisms for satisfying goals that are central to the law-though only to the extent that the economist's descriptions of individual responses to legal rules could be empirically validated.

\section{An economic argument against the economics of liability}

Despite their concerns about whether economics could usefully inform legal decision making, Blum and Kalven were convinced that they could turn economic logic to their advantage in rebutting Calabresi's claim that strict liability for auto accidents - putting the costs of accidents on motorists - is preferable to a common law negligence system. They initially sketched this argument in a 1966 exchange of memoranda and repeated the claim in their 1967 article, noting

\footnotetext{
${ }^{39}$ Document 6, "Notes," p. 3. Blum and Kalven seem to have been of the mind that Stigler's desire to achieve an appropriate level of deterrence but yet separate deterrence from compensation for victims would be satisfied via a general tax on motorists (an idea to which they did not seem to be completely opposed, since it would fall on all motorists and not just those involved in accidents), a la Calabresi, combined with a transfer scheme such as the one they proposed in their 1964 article. What Blum and Kalven seem not to have realized is that the economist would argue that their transfer scheme does impact incentives, and thus efficiency, by reducing the level of precaution on the part of potential victims.
} 
in the process that they had "benefitted greatly from discussions with Harold Demsetz" in the formulation of their arguments and pointing to "two especially relevant pieces by economists"Demsetz's “The Exchange and Enforcement of Property Rights” (1964) and Simon Rottenberg's "Liability in Law and Economics" (1965)—-that had informed their thinking (Blum and Kalven 1967, 239n.1). ${ }^{40}$

Certainly, Blum and Kalven agreed, one could accept the economist's claim in favor of the imposition of liability on manufacturers of potentially dangerous products, as this would indeed accomplish the desired level of deterrence at least cost. Strict liability puts the costs on the manufacturers, but a portion of these costs are passed on to consumers of these products in the form of higher prices. If the costs and thus prices are properly set, the products' users are exposed to the potential costs associated with using the product, meaning that the relevant costs will be internalized to both parties at the lowest cost to society $(1967,248-49)$. However, they asserted, the same result would not obtain in automobile accident law if all costs were placed on motorists - the accident-law equivalent of the manufacturer — and for two reasons. First, unlike the manufacturer, the motorist cannot easily estimate accident risk and associated losses. Second one cannot justify strict liability on the grounds that market forces will see to the proper allocation of costs. While consumers bear a share of the costs in products liability cases (either through harm incurred or higher prices), the absence of a pricing system to reallocate potential costs associated with auto accidents means that these costs fall on motorists if they are liable and on the victims if they are liable (pp. 250-251). One cannot then presume that motorists will bear the appropriate share of accident costs regardless of where liability is assigned, and thus the

\footnotetext{
${ }^{40}$ Rottenberg was at that time a Professor of Economics at SUNY-Buffalo, having previously served on the faculty at Chicago.
} 
structure of law here, unlike in the products liability case, will affect the ultimate allocation of costs.

Their conversations with Demsetz and immersion in the literature of economics, though, did nothing to deter Blum and Kalven from their dim view of the price-related deterrent effects of legal rules, as least as applied to accidents. Blum and Kalven's article saw them continue to emphasize that the deterrent effect of strict liability is unlikely to be significant because drivers already face the potential harm to themselves associated with accidents. This risk alone induces drivers to exercise maximum care, or something approaching it, and adding to this the potential costs associated with harm to others, they argued, is not likely to increase the safety with which people drive. Here, then, we find Blum and Kalven taking an economic position that would be unrecognizable to their economist colleagues at Chicago. The claim, in short, is that there are limits to the link between costs and behavior. In the present instance, the costs associated with the risk to personal safety do indeed have a deterrent effect, but this effect is so substantial that the benefits associated with further cost internalization would be zero $(1967,254)$. And even if one allows that some people will respond to additional cost-internalization incentives, Blum and Kalven suggested that the difficulties of structuring insurance premiums to accomplish this would be practically insurmountable. This, along with other factors, such as the costs associated with drivers using slower speeds, the need to alter/build roads to account for these slower average speeds etc., raise the specter of further costs which, contrary to Calabresi's claim, may make the strict liability scheme inefficient. Moreover, they alleged, the strict liability approach does not offer the prospect of deterring most those motorists most likely to be involved in accidents (in contrast to a fault-based system) and, because of the absence of a market process 
for reallocating costs, does not induce potential non-motorist victims to take sufficient precaution (1967, 255-59). When all of these effects were taken into account, it was not clear to Blum and Kalven that a move to strict liability would, in fact, "yield ... a net reduction in costs to society" $(1967,259)$. Differently put, strict liability may well fail to satisfy the economic efficiency standard that Calabresi was using to justify it.

Perhaps the most serious difficulty with the application of the economic approach, Blum and Kalven repeatedly stressed, is fact that we do not know what the optimum is and thus cannot say whether putting any particular share of costs on motorists will move us any closer to it. ${ }^{41}$ The standards for making such a determination were unrealistically stringent, in their view, so much so that they came away from a conversation with Demsetz feeling that, "[i]n essence, [the economic] approach is based upon the notion that we might be semi-omniscient, but not wholly so." ${ }^{42}$ The idea that the analyst could determine or even get a sense for the optimal number of auto accidents, they said, gives accident law “a science-fiction flavor" $(1967,262)$. Thus, while a system based on economics might be "perfect," it would also be "Utopian" $(1967,263)$.

What is interesting about Blum and Kalven's criticism of the optimality standard is that it seems to part company with Demsetz's view of the appropriate "economic" approach to such problems in two important ways. First, Blum and Kalven — consistent with their emphasis on "justice"-were assuming that all victims must be fully compensated, whereas the wealth maximization approach advocated by Demsetz (and by Coase) does not necessitate this. Second, Blum and Kalven appear to ignore the costs associated with administering the social insurance

\footnotetext{
${ }^{41}$ See, e.g., Document 7, “A Note on the Calabresi Formulation,” p. 2.

${ }^{42}$ Document 4, p. 1. They also note here that this is the basic position taken by Stigler. Interestingly, semiomniscience was replaced with "omniscience" in their 1967 article.
} 
scheme that was their preferred method for accident-loss compensation. The determination of the optimal number of auto accidents requires building into the system all costs that vary with the number of accidents, and these include the costs of administering the compensation system. That Blum and Kalven did not put such costs on a par with the more direct costs associated with auto accidents is reflected in the introduction to the 1965 book version of their original article, where they note that "On our scale these matters are entitled to weight, but only as by-products and side effects of adopting a plan" (1965, vi). Here too, then, Blum and Kalven were not prepared to go all the way with the economist's wealth-maximization approach. What makes this all the more curious is their insistence, in their private writings leading up to the publication of their article, that Calabresi was remiss in not considering the indirect costs associated with his own proposed revision of accident law. Blum and Kalven, the evidence suggests, were guilty of another version of the same sin. In attempting to push the limits of the "economic approach" and adapt it to their purposes, it would seem that they were still not able to completely loose themselves from other concerns.

\section{Conclusions}

The story of the origins of the economic analysis of law is often portrayed as an exercise in economics imperialism (e.g., Duxbury, 1995, 367-377; Fine and Milonakis 2009). But there is a growing body of evidence to suggest that this was anything but the case and thus that the traditional view is misguided at best. As Medema (2014a) has demonstrated, it was lawyers, not economists, who brought the Coase theorem to bear on law in the 1960s, and the place of a "Chicago school" in that history is anything but central. ${ }^{43}$ The present paper adds weight to this

\footnotetext{
${ }^{43}$ See also Medema (2017) for a more broad-based historical discussion of the "imperialism" question as it pertains
} to the economic analysis of law. On how economists understood "The Problem of Social Cost" and used the Coase 
alternative perspective on legal-economic history by focusing on the interactions between lawyers and economists at Chicago and the earliest steps toward interdisciplinarity. The lawyers at Chicago are central to the story here, and these legal scholars were reaching out to economists for insights that would further their efforts to determine whether, and the extent to which, economic thinking could properly inform legal analysis and how that thinking might shed light on a legal issue of major social and legal importance.

What our analysis reveals is that all of the players examined here have in common a sense that economic thinking can be fruitfully applied to the analysis of legal issues. Where they differed was in the utility, appropriateness, and extent to which one should do so, and the conclusions that one could, and should, properly draw from the analysis so applied. In short, the interdisciplinary effort that became known as the economic analysis of law was alive and well at Chicago throughout the 1960s in areas beyond antitrust, but the perspectives on how economic analysis should inform law and the lessons to be taken from it were anything but homogeneous.

\section{References}

Anderson, James M., Paul Heaton and Stephen J. Carroll. 2010. The U.S. Experience with NoFault Automobile Insurance. A Retrospective, Rand Institute for Civil Justice, Rand Corporation.

Blum, Walter J. and Harry Kalven, Jr. 1952. "The Uneasy Case for Progressive Taxation,” University of Chicago Law Review, 19 (3), pp. 417-520.

Blum, Walter J. and Harry Kalven, Jr. 1953. The Uneasy Case for Progressive Taxation, Chicago, Chicago University Press.

theorem during this period, see Marciano and Frischmann (2015) and Medema (2014c). 
Blum, Walter J. and Harry Kalven, Jr. 1964. "Public Law Perspectives on a Private Law Problem: Auto Compensation Plans," University of Chicago Law Review, 31 (4), pp. 641723.

Blum, Walter J. and Harry Kalven, Jr. 1965. Public Law Perspectives on a Private Law Problem: Auto Compensation Plans. Boston: Little, Brown \& Company.

Blum, Walter J. and Harry Kalven, Jr. 1967. “The Empty Cabinet of Dr. Calabresi: Auto Accidents and General Deterrence," University of Chicago Law Review, 34 (2), pp. 239-73.

Calabresi, Guido. 1961. "Some Thoughts on Risk Distribution and the Law of Torts," Yale Law Journal, 70 (4), pp. 499-553.

Calabresi, Guido. 1965a. "The Decision for Accidents: An Approach to Nonfault Allocation of Costs," Harvard Law Review 78 (4), pp. 713-45.

Calabresi, Guido. 1965b. "Fault, Accidents and the Wonderful World of Blum and Kalven," Yale Law Journal 75 (2), pp. 216-38.

Calabresi, Guido. 1975. "Concerning Cause and the Law of Torts: An Essay for Harry Kalven, Jr.," University of Chicago Law Review, 43, pp. 69-108.

Coase, Ronald H. 1960. "The Problem of Social Cost," Journal of Law and Economics, 3 (Oct.), pp. 1-44.

Coase, Ronald H. 1993. "Law and Economics at Chicago," Journal of Law and Economics, 36 (1), pp. 239-54.

Conard, Alfred. 1964. “The Economic Treatment of Automobile Injuries,” Michigan Law Review, 63(2), pp. 279-326. 
Conard, Alfred, James Morgan, Robert Pratt, Jr., Charles Voltz and Robert Bombaugh. 1964. Automobile Accidents Costs and Payments : Studies in the Economics of Insuring Reparations, Michigan Legal Studies, University of Michigan Press.

Demsetz, Harold. 1964. "The Exchange and Enforcement of Property Rights," Journal of Law and Economics, 7 (Oct.), pp. 11-26.

Director, Aaron. 1952. Defense, Controls and Inflation, Chicago, Chicago University Press.

Duxbury, Neil. 1995. Patterns of American Jurisprudence, Oxford: Oxford University Press.

Ehrenzweig, A. 1951. Negligence Without Fault. Berkeley, CA: University of California Press.

Ehrenzweig, A. 1955. "Full Aid Insurance for the Traffic Victim-A Voluntary Compensation Plan,” California Law Review, 43(1), pp. 1-48.

Ben Fine and Dimitris Milonakis. 2009. From Economics Imperialism to Freakonomics: The Shifting Boundaries Between Economics and Other Social Sciences. London: Routledge.

Fleury, Jean-Baptiste. 2015. "Massive Influence with Scarce Contributions: the rationalizing economist Gary S. Becker, 1930-2014,” European Journal of Law and Economics, 39 (1), pp. 3-9.

Flink, James J. 1972. “Three Stages of American Automobile Consciousness,” American Quarterly, 24 (4), pp. 451-473.

Franklin, Marc A. , Robert H. Chanin and Irving Mark. 1961. "Accidents, Money, and the Law: A Study of the Economics of Personal Injury Litigation," Columbia Law Review, 61 (1), pp. 1-39.

Green, Leon. 1958. Traffic Victims: Tort Law and Insurance, Evanston, Northwestern University 
Press.

Gregory, Charles O. and Harry Kalven, Jr. 1959. Cases and Materials on Torts, Little, Brown.

Harnay, Sophie and Alain Marciano. 2009. "Posner, Economics and the Law: From 'Law and Economics' to an Economic Analysis of Law," Journal of the History of Economic Thought, 31(2), pp. 215-232.

James, Flemming Jr. 1959. "The Columbia Study of Compensation for Automobile Accidents: An Unanswered Challenge," Columbia Law Review, 59: 408-424.

James, Flemming Jr. and S. Law. 1952. "Compensation for Auto Accident Victims_A Story of Too Little and Too Late," Connecticut Bar Journal, 26(1), pp. 70-81.

Kalven, Jr. Harry. 1955. "Review of Albert Armin Ehrenzweig, "Full Aid" Insurance for the Traffic Victim: A Voluntary Compensation Plan," 33 Texas Law Review 778.

Kalven, Jr. Harry. 1956. “The Jury in Auto Cases: Invitation to Research,” Virginia Law Weekly, 22.

Kalven, Jr. Harry. 1957. “Compulsory Auto Insurance,” Chicago Sun-Times, Nov 24, p. 3. Kalven, Jr. Harry.1959. "Review of Leon Green, Traffic Victims: Tort Law and Insurance," University of Chicago Law Review, 26 (4), pp. 679-686.

Kitch, Edmund W. 1983. "The Fire of Truth: A Remembrance of Law and Economics at Chicago, 1932-1970,” Journal of Law and Economics, 26 (1), pp. 163-234

Marciano, Alain. 2012. “Guido Calabresi’s Economic Analysis of Law, Coase and the Coase theorem," International Review of Law and Economics, 32 (1), pp. 110-118..

Marciano, Alain and Giovanni Ramello. 2014. "Consent, Choice and Guido Calabresi's 
Heterodox Economic Analysis Of Law," Law and Contemporary Problems, 77 (2), pp. 97 116.

Marciano, Alain and Brett Frischmann. 2015. "Understanding The Problem of Social Cost," Journal of Institutional Economics, 11 (2), pp. 329-352.

Marciano, Alain and Rustam Romaniuc. 2015. "Accident costs, resource allocation and individual rationality: Blum, Kalven, and Calabresi," European Journal of the History of Economic Thought, 22 (6), pp. 1084-1114.

McCord Wright, David. 1954. "Review of The Uneasy Case for Progressive Taxation by Walter J. Blum; Harry Kalven," Stanford Law Review, 6 (3), pp. 583-584

Medema, Steven G. 1998. "Wandering the Road From Pluralism to Posner: The Transformation of Law and Economics, 1920s-1970s," In The Transformation of American Economics: From Interwar Pluralism to Postwar Neoclassicism: History of Political Economy Annual Supplement, 30, pp. 202-24.

Medema, Steven G. 2014a. "Debating Law's Irrelevance: Legal Scholarship and the Coase Theorem in the 1960s," Texas A\&M Law Review 2 (2), pp.159-213.

Medema, Steven G. 2014b. “Juris Prudence: Calabresi's Uneasy Relationship with the Coase Theorem," Law and Contemporary Problems 77 (2), pp. 65-95.

Medema, Steven G. 2014c. "1966 and All That: The Birth of the Coase Theorem Controversy," Journal of the History of Economic Thought 36 (3): 271-303.

Medema, Steven G. 2017. "Scientific Imperialism or Merely Boundary Crossing? Economists, Lawyers, and the Coase Theorem at the Dawn of the Economic Analysis of Law," in 
Uskali Mäki, Adrian Walsh, and Manuela Fernández Pinto, eds., Scientific Imperialism:

Exploring the Boundaries of Interdisciplinarity. London: Routledge, pp. 89-116.

Plant, Marcus L. 1955. "Review of "Full Aid" Insurance for the Traffic Victim by A. A.

Ehrenzweig, and The Law of Compulsory Motor Vehicle Insurance in South Africa. A Treatise on the Motor Vehicle Insurance Act by A. Suzman and G. Gordon," American Journal of Comparative Law, 4 (1), pp. 117-121.

Posner, Richard A. 1972. Economic Analysis of Law. Little, Brown and Co. New York.

Posner, Richard A. 1987. "The Decline of Law as an Autonomous Discipline," Harvard Law Review, 100 (4), pp. 761-780.

Rothbard, Murray N. 2010. Strictly Confidential: The Private Volker Fund Memos of Murray N. Rothbard, edited by David Gordon, LVMI.

Rottenberg, Simon. 1956. “The Baseball Players' Labor Market,” Journal of Political Economy, 64 (June), pp. 242-58.

Rottenberg, Simon. 1965. "Liability in Law and Economics," American Economic Review 55 (March), pp.107-144.

Shaviro, Daniel. 2013. “The Forgotten Henry Simons," Florida State University Law Review, 41 (1), pp. 2-38.

Simons, Heny C. 1938. Personal income taxation; the definition of income as a problem of fiscal policy, Chicago, Chicago University Press.

Stigler, George. 1966. The Theory of Price, Chicago, Chicago University Press.

Van Horn, Robert and Philip Mirowski. 2009. "The Rise of the Chicago School of Economics," 
in The Road from Mont Pelerin. Philip Mirowski and Dieter Plehwe eds. Cambridge:

Harvard University Press, pp. 139-178.

Van Horn, Robert. 2009. "Reinventing Monopoly and Corporations: The Roots of Chicago Law and Economics," in The Road from Mont Pelerin. Philip Mirowski and Dieter Plehwe eds. Cambridge: Harvard University Press, pp. 204-237.

Woodard, Calvin. 1988. "Charles O. Gregory," Virginia Law Review, 74 (1), pp. 3-10. 